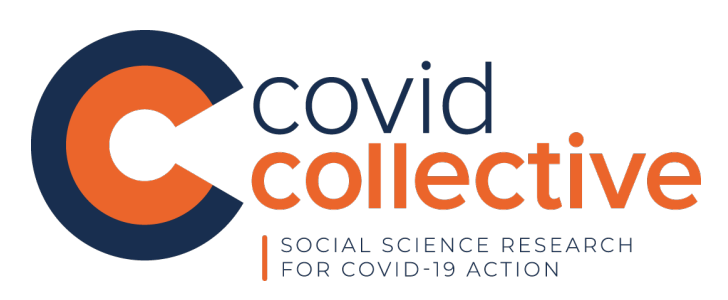

\title{
Key global policy dates and engagement opportunities for the Covid Collective
}

\author{
L. Bolton \\ Institute of Development Studies \\ 23 March 2021
}

\section{Question}

- Map key international and national days, events, moments relating to COVID19 (e.g. health, socio-economic, inclusion impacts) to inform Covid Collective's schedule of publications and activities. Mapping should include:

- UN/international days

- Global events, e.g. COP 26

- National days/key events in Covid Collective countries

- Key milestones, anniversaries tied to the pandemic

\section{Contents}

1. International meetings

2. Research conferences and webinars

3. Calendar of designated days/weeks

4. Anniversaries

\footnotetext{
The Covid Collective helpdesk service provides brief summaries of current research, evidence, and lessons learned. Helpdesk reports are not rigorous or systematic reviews; they are intended to provide an introduction to the most important evidence related to a research question. They draw on a rapid desk-based review of published literature and consultation with subject specialists.

This Helpdesk report was commissioned through the Covid Collective based at the Institute of Development Studies (IDS) and is funded by the UK Foreign, Commonwealth and Development Office (FCDO). The Collective brings together the expertise of UK and Southern based research partner organisations and offers a rapid social science research response to inform decision-making on some of the most pressing COVID-19 related development challenges. The views and opinions expressed do not necessarily reflect those of FCDO, the UK Government, or any other contributing organisation. For further information, please contact covidcollective@ids.ac.uk.
} 


\section{International meetings}

\begin{tabular}{|c|c|c|}
\hline Date(s) & Event & $\begin{array}{l}\text { Covid } \\
\text { Collective } \\
\text { theme }\end{array}$ \\
\hline $\begin{array}{l}\text { 5-11 April } \\
2021\end{array}$ & $\begin{array}{l}2021 \text { Spring Meetings of the World Bank } \\
\text { Group and the International Monetary Fund } \\
\text { Key events are the World Bank Opening Press Conference (7 } \\
\text { April), International Monetary and Financial Committee (IMFC) } \\
\text { meeting (8 April), and the Development Committee Meeting (9 } \\
\text { April). } \\
\text { Events include: } \\
5 \text { April: Capacity Development Talk: The IMF's Engagement on } \\
\text { Social Protection. } \\
6 \text { April: Leveraging the Post-Pandemic Recovery for a Green } \\
\text { Transition in Europe and Central Asia. } \\
\text { Capacity Development Talk: Supporting COVID-19 Spending } \\
\text { Transparency through Digital Platforms } \\
\text { Averting a CoVID-19 Debt Trap } \\
7 \text { April: A Peek Into Training: Achieving Inclusive Growth } \\
\text { Analytical Corner - Session 2: Inequality/Debt } \\
\text { Rethinking Debt: Financing the Future Amid Crisis } \\
9 \text { April: COVID-19: Vaccines for Developing Countries } \\
\text { https://www.worldbank.org/en/meetings/splash/spring/overview }\end{array}$ & $\begin{array}{l}\text { Governance } \\
\text { Social } \\
\text { inclusion }\end{array}$ \\
\hline $\begin{array}{l}13-15 \text { and } \\
20-22 \text { April }\end{array}$ & $\begin{array}{l}\text { World Health Organization (WHO) Fair Pricing } \\
\text { Forum } \\
\text { Organised in-line with the World Health Assembly adopted } \\
\text { Resolution WHA } 72.8 \text { on Improving the transparency of markets } \\
\text { for medicines, vaccines, and other health products. } \\
\text { Representatives are brought together from member states to } \\
\text { share experience, advance discussions on pricing and Research } \\
\text { \& Development, and to activate additional country support. }\end{array}$ & $\begin{array}{l}\text { Governance } \\
\text { Social } \\
\text { inclusion }\end{array}$ \\
\hline
\end{tabular}




\begin{tabular}{|c|c|c|}
\hline & $\begin{array}{l}\text { https://www.who.int/news- } \\
\text { room/events/detail/2021/04/13/default-calendar/fair-pricing- } \\
\text { forum-2021 }\end{array}$ & \\
\hline 19-30 April & $\begin{array}{l}\text { Permanent Forum on Indigenous Issues, } \\
\text { twentieth session } \\
\text { Theme: 'Peace, justice and strong institutions: the role of } \\
\text { indigenous peoples in implementing Sustainable Development } \\
\text { Goal 16'. } \\
\text { https://www.un.org/development/desa/dspd/2021/03/unpfii/ } \\
\text { A preparation meeting was held in December } 2020 \text { where } \\
\text { experts gathered on the theme 'Indigenous Peoples and } \\
\text { Pandemics'. } \\
\text { https://www.un.org/development/desa/indigenouspeoples/egm- } \\
\text { indigenous-peoples-and-pandemics.html }\end{array}$ & $\begin{array}{l}\text { Social } \\
\text { inclusion }\end{array}$ \\
\hline 6-7 May & $\begin{array}{l}\text { High-level Meeting of the Development } \\
\text { Cooperation Forum (DCF) } \\
\text { Aiming to advance international development cooperation that } \\
\text { reduces risk, enables recovery and builds resilience in the } \\
\text { COVID-19 period and beyond. } \\
\text { The DCF is the principal global platform for policy dialogue on } \\
\text { development cooperation. Discussions are reality-based, action- } \\
\text { oriented and results-focused. } \\
\text { https://www.un.org/development/desa/financing/events/2021- } \\
\text { high-level-meeting-development-cooperation-forum-dcf }\end{array}$ & $\begin{array}{l}\text { Governance } \\
\text { Social } \\
\text { inclusion }\end{array}$ \\
\hline 12-14 May & $\begin{array}{l}\text { International Conference on Public Health in } \\
\text { Africa } \\
\text { Organised by the African Union Commission. Focus on COVID-19 } \\
\text { in Africa one year on. Reviewing lessons and the opportunity to } \\
\text { re-evaluate public health practice. } \\
\text { https://10times.com/e1sr-1109-dxkr }\end{array}$ & $\begin{array}{l}\text { Governance } \\
\text { Social } \\
\text { inclusion }\end{array}$ \\
\hline
\end{tabular}




\begin{tabular}{|c|c|c|}
\hline $\begin{array}{l}24 \text { May - } 1 \\
\text { June }\end{array}$ & $\begin{array}{l}\text { Seventy-fourth World Health Assembly } \\
\text { The decision-making body of the WHO attended by delegations } \\
\text { from all WHO member states. Agenda not yet published. } \\
\text { https://www.who.int/about/governance/world-health-assembly }\end{array}$ & $\begin{array}{l}\text { Governance } \\
\text { Social } \\
\text { inclusion }\end{array}$ \\
\hline 7-18 June & $\begin{array}{l}\text { 109th Session of the International Labour } \\
\text { Conference } \\
\text { Agenda includes: } \\
\text { A general discussion on 'Inequalities and the world of work' } \\
\text { 'A recurrent discussion on the strategic objective of social } \\
\text { protection (social security), under the follow-up to the ILO } \\
\text { Declaration on social Justice for a Fair Globalization' } \\
\text { https://www.ilo.org/ilc/ILCSessions/109/lang--en/index.htm } \\
\text { Background report: Promoting employment and decent work in } \\
\text { a changing landscape. } \\
\text { https://www.ilo.org/ilc/ILCSessions/109/reports/reports-to-the- } \\
\text { conference/WCMS_775883/lang--en/index.htm }\end{array}$ & $\begin{array}{l}\text { Governance } \\
\text { Social } \\
\text { inclusion }\end{array}$ \\
\hline 11-13 June & $\begin{array}{l}\text { G7 Leaders' Summit } 2021 \\
\text { Meeting focus: building back better from the COVID-19 } \\
\text { pandemic. Particularly: global recovery and strengthening } \\
\text { resilience; promoting prosperity through free and fair trade; } \\
\text { tackling climate change; and championing global shared values. } \\
\text { https://sdg.iisd.org/events/g7-leaders-summit-2027/ }\end{array}$ & $\begin{array}{l}\text { Governance } \\
\text { Social } \\
\text { inclusion }\end{array}$ \\
\hline 15-17 June & $\begin{array}{l}\text { 14th session of the Conference of States } \\
\text { Parties to the Convention on the Rights of } \\
\text { Persons with Disabilities } \\
\text { Theme: meeting the needs, realising the rights and addressing } \\
\text { the socio-economic impacts of COVID-19 on persons with } \\
\text { disabilities. Sub themes: 1) protecting rights in armed conflict } \\
\text { and humanitarian emergencies; 2) living independently and } \\
\text { being included in the community; and 3) access to education } \\
\text { during COVID-19. }\end{array}$ & $\begin{array}{l}\text { Social } \\
\text { inclusion }\end{array}$ \\
\hline
\end{tabular}




\begin{tabular}{|c|c|c|}
\hline & $\begin{array}{l}\text { https://www.un.org/development/desa/disabilities/conference- } \\
\text { of-states-parties-to-the-convention-on-the-rights-of-persons- } \\
\text { with-disabilities-2/cosp14.html }\end{array}$ & \\
\hline 21-26 June & $\begin{array}{l}\text { Commonwealth Heads of Government } \\
\text { Meeting (CHOGM) } \mathbf{2 0 2 1} \\
\text { Theme: Delivering a Common Future: Connecting, Innovating, } \\
\text { Transforming. https://thecommonwealth.org/chogm } \\
\text { Special forums are held to ensure marginalised voices are heard: } \\
\text { 20-22 June: } 2021 \text { Commonwealth Youth Forum in Rwanda. } \\
\text { Theme: 'Taking Charge of Our Future' } \\
\text { https://thecommonwealth.org/media/event/event-2021- } \\
\text { commonwealth-youth-forum-rwanda } \\
\text { 21-22 June: } 2021 \text { Commonwealth Women's Forum in Rwanda. } \\
\text { Theme: 'Delivering a Common Future: Transforming for } \\
\text { Equitable Access and Inclusive Growth' } \\
\text { https://thecommonwealth.org/media/event/event-2021- } \\
\text { commonwealth-women\%E2\%80\%99s-forum-rwanda } \\
\text { 21-25 June: } 2021 \text { Commonwealth People's Forum in Rwanda. } \\
\text { Theme: 'Advancing Together: Delivering people-centred } \\
\text { governance through the Commonwealth' } \\
\text { https://thecommonwealth.org/media/event/event-2020- } \\
\text { commonwealth-peoples-forum-rwanda }\end{array}$ & $\begin{array}{l}\text { Governance } \\
\text { Social } \\
\text { inclusion }\end{array}$ \\
\hline 23-25 June & $\begin{array}{l}\text { UN Economic and Social Council's (ECOSOC) } \\
\text { Humanitarian Affairs Segment } \mathbf{2 0 2 1} \\
\text { Meeting of Member States, UN entities, humanitarian and } \\
\text { development partners, the private sector and affected } \\
\text { communities to discuss emerging and pressing humanitarian } \\
\text { issues. } \\
\text { https://sdg.iisd.org/events/ecosoc-humanitarian-affairs- } \\
\text { segment-2021/ }\end{array}$ & $\begin{array}{l}\text { Governance } \\
\text { Social } \\
\text { inclusion }\end{array}$ \\
\hline 6-15 July & $\begin{array}{l}\text { High-Level Political Forum } 2021 \text { Under the } \\
\text { Auspices of the Economic and Social Council } \\
\text { (ECOSOC) } \\
\text { Theme: 'Sustainable and resilient recovery from the COVID-19 } \\
\text { pandemic that promotes the economic, social and }\end{array}$ & Governance \\
\hline
\end{tabular}




\begin{tabular}{|c|c|c|}
\hline & $\begin{array}{l}\text { environmental dimensions of sustainable development: building } \\
\text { an inclusive and effective path for the achievement of the } 2030 \\
\text { Agenda in the context of the decade of action and delivery for } \\
\text { sustainable development'. } \\
\text { Discussing Sustainable Development Goals (SDGs) } 1 \text { on no } \\
\text { poverty, } 2 \text { on zero hunger, } 3 \text { on good health and well-being, } 8 \text { on } \\
\text { decent work and economic growth, } 10 \text { on reduced inequalities, } \\
12 \text { on responsible consumption and production, } 13 \text { on climate } \\
\text { action, } 16 \text { on peace, justice and strong institutions, and } 17 \text { on } \\
\text { partnerships in depth. } \\
\text { https://sustainabledevelopment.un.org/hlpf/2021 }\end{array}$ & $\begin{array}{l}\text { Social } \\
\text { inclusion }\end{array}$ \\
\hline 12 July & $\begin{array}{l}\text { ECOSOC Local and Regional Governments } \\
\text { Forum } \\
\text { No further information is available for this event at the time of } \\
\text { writing. } \\
\text { https://sdgs.un.org/events/local-and-regional-governments- } \\
\text { forum-32572 }\end{array}$ & Governance \\
\hline 14 July & $\begin{array}{l}\text { Special Event on SDG Acceleration Actions } \\
\text { Information for this event not yet available. } \\
\text { https://sdgs.un.org/events/special-event-sdg-acceleration- } \\
\text { actions-32573 }\end{array}$ & $\begin{array}{l}\text { Governance } \\
\text { Social } \\
\text { inclusion }\end{array}$ \\
\hline $\begin{array}{l}30 \text { August } \\
-3 \\
\text { September }\end{array}$ & $\begin{array}{l}\text { Immunization and vaccines related } \\
\text { implementation research advisory committee } \\
\text { (IVIR-AC) } \\
\text { No information available yet for this event. } \\
\text { https://www.who.int/news- } \\
\text { room/events/detail/2021/08/30/default-calendar/immunization- } \\
\text { and-vaccines-related-implementation-research-advisory- } \\
\text { committee-(ivir-ac)---september-2021 }\end{array}$ & Governance \\
\hline
\end{tabular}




\begin{tabular}{|c|c|c|}
\hline $\begin{array}{l}5-7 \\
\text { October }\end{array}$ & $\begin{array}{l}\text { Strategic Advisory Group of Experts on } \\
\text { Immunization (SAGE) } \\
\text { Meeting materials will be made available nearer the time. } \\
\text { https://www.who.int/news- } \\
\text { room/events/detail/2027/10/05/default- } \\
\text { calendar/sage_meeting_october_2027 }\end{array}$ & Governance \\
\hline $\begin{array}{l}1-12 \\
\text { November }\end{array}$ & $\begin{array}{l}\text { UN Climate Change Conference of the Parties } \\
\text { (COP26) } \\
\text { Hosted in Glasgow. } \\
\text { https://ukcop26.org/ }\end{array}$ & $\begin{array}{l}\text { Governance } \\
\text { Social } \\
\text { inclusion }\end{array}$ \\
\hline $\begin{array}{l}\text { 7-11 March } \\
2022\end{array}$ & $\begin{array}{l}\text { Immunization and vaccines related } \\
\text { implementation research advisory committee } \\
\text { (IVIR-AC) } \\
\text { https:/www.who.int/news- } \\
\text { room/events/detail/2022/03/07/default-calendar/immunization- } \\
\text { and-vaccines-related-implementation-research-advisory- } \\
\text { committee-(ivir-ac)---march-2022 }\end{array}$ & $\begin{array}{l}\text { Governance } \\
\text { Social } \\
\text { inclusion }\end{array}$ \\
\hline
\end{tabular}

\section{Research conferences and webinars}

\begin{tabular}{|l|l|l|}
\hline Date(s) & Event & $\begin{array}{l}\text { Covid } \\
\text { Collective } \\
\text { theme }\end{array}$ \\
\hline 29 March & $\begin{array}{l}\text { World Bank webinar: Tackling the } \\
\text { COVID-19 Pandemic of Inequality to } \\
\text { Build a Green, Inclusive, \& Resilient } \\
\text { Recovery } \\
\text { World Bank Group President David Malpass discusses } \\
\text { green, inclusive, and resilient recovery at the London } \\
\text { School of Economics. }\end{array}$ & Governance \\
\hline
\end{tabular}




\begin{tabular}{|c|c|c|}
\hline & $\begin{array}{l}\text { https://live.worldbank.org/tackling-Covid19-pandemic- } \\
\text { green-inclusive-resilient-recovery }\end{array}$ & $\begin{array}{l}\text { Social } \\
\text { inclusion }\end{array}$ \\
\hline 9 April & $\begin{array}{l}\text { World Bank webinar: COVID-19: } \\
\text { Vaccines for Developing Countries } \\
\text { An event to explore work underway for vaccine rollout, } \\
\text { the private sector's role, and reflecting on opportunities } \\
\text { and challenges to build more resilient health and } \\
\text { economic systems. } \\
\text { https://live.worldbank.org/Covid-19-vaccines- } \\
\text { developing-countries }\end{array}$ & $\begin{array}{l}\text { Governance } \\
\text { Social } \\
\text { inclusion }\end{array}$ \\
\hline 28 April & $\begin{array}{l}\text { Sustaining the Response: Vaccine } \\
\text { Access and Diplomacy. How is the } \\
\text { effort to ensure global access to } \\
\text { vaccines progressing? } \\
\text { Chatham house webinar. } \\
\text { https://www.chathamhouse.org/events/all/members- } \\
\text { event/sustaining-response-vaccine-access-and- } \\
\text { diplomacy }\end{array}$ & $\begin{array}{l}\text { Governance } \\
\text { Social } \\
\text { inclusion }\end{array}$ \\
\hline 24-25 May & $\begin{array}{l}\text { International Conference on Social, } \\
\text { Political and Economic Trends } \\
\text { https://waset.org/social-political-and-economic-trends- } \\
\text { conference-in-may-2027-in-montreal }\end{array}$ & $\begin{array}{l}\text { Governance } \\
\text { Social } \\
\text { inclusion }\end{array}$ \\
\hline 24-25 May & $\begin{array}{l}\text { International Conference on Social and } \\
\text { Political Issues } \\
\text { https://waset.org/social-and-political-issues- } \\
\text { conference-in-may-2027-in-montreal }\end{array}$ & $\begin{array}{l}\text { Governance } \\
\text { Social } \\
\text { inclusion }\end{array}$ \\
\hline
\end{tabular}




\begin{tabular}{|c|c|c|}
\hline 24-25 June & $\begin{array}{l}\text { International Conference on Social, } \\
\text { Economic and Cultural } \\
\text { Transformations } \\
\text { https://waset.org/social-economic-and-cultural- } \\
\text { transformations-conference-in-june-2027-in-oslo }\end{array}$ & $\begin{array}{l}\text { Governance } \\
\text { Social } \\
\text { inclusion }\end{array}$ \\
\hline 12-13 July & $\begin{array}{l}\text { International Conference on Poverty } \\
\text { and Social Protection } \\
\text { https://waset.org/poverty-and-social-protection- } \\
\text { conference-in-july-2027-in-ottawa }\end{array}$ & $\begin{array}{l}\text { Social } \\
\text { inclusion }\end{array}$ \\
\hline $\begin{array}{l}30 \text { August } \\
-1 \\
\text { September }\end{array}$ & $\begin{array}{l}\text { Achieving Sustainable Development in } \\
\text { the Least Developed Countries - LDC } \\
\text { Future Forum } \\
\text { Addressing structural impediments to sustainable } \\
\text { development. } \\
\text { https://www.wider.unu.edu/event/achieving- } \\
\text { sustainable-development-least-developed-countries- } \\
\text { Idc-future-forum }\end{array}$ & $\begin{array}{l}\text { Governance } \\
\text { Social } \\
\text { inclusion }\end{array}$ \\
\hline $\begin{array}{l}6-8 \\
\text { September }\end{array}$ & $\begin{array}{l}\text { COVID-19 and development - effects } \\
\text { and new realities for the Global South } \\
\text { A platform for sharing knowledge on the effects of the } \\
\text { pandemic in different regions and what can be done to } \\
\text { support recovery. } \\
\text { https://www.wider.unu.edu/event/Covid-19-and- } \\
\text { development-effects-and-new-realities-global-south }\end{array}$ & $\begin{array}{l}\text { Governance } \\
\text { Social } \\
\text { inclusion }\end{array}$ \\
\hline $\begin{array}{l}8-9 \\
\text { September }\end{array}$ & $\begin{array}{l}\text { 9th International Conference on } \\
\text { Sustainable Development } \\
\text { Theme: Creating a unified foundation for Sustainable } \\
\text { Development: Research, Practice and Education. } \\
\text { https://euagenda.eu/events/2027/09/08/icsd-2021-9th- } \\
\text { international-conference-on-sustainable- } \\
\text { development-8-9-september-rome-italy }\end{array}$ & $\begin{array}{l}\text { Governance } \\
\text { Social } \\
\text { inclusion }\end{array}$ \\
\hline
\end{tabular}




\begin{tabular}{|l|l|l|}
\hline & $\begin{array}{l}\text { International Conference on } \\
\text { Development, Urban Space, and } \\
\text { Human Rights in Africa }\end{array}$ & \\
& $\begin{array}{l}\text { Governance } \\
\text { https://waset.org/development-urban-space-and- } \\
\text { 7-8 } \\
\text { October } \\
\text { tokyo }\end{array}$ & $\begin{array}{l}\text { Social } \\
\text { inclusion }\end{array}$ \\
\hline
\end{tabular}

\section{Calendar of designated days/weeks}

\begin{tabular}{|c|c|c|}
\hline Date & Day/week & $\begin{array}{l}\text { Covid } \\
\text { Collective } \\
\text { theme }\end{array}$ \\
\hline 7 April & $\begin{array}{l}\text { World Health Day } \\
\text { https://www.who.int/westernpacific/news/events/world- } \\
\text { health-day }\end{array}$ & $\begin{array}{l}\text { Governance } \\
\text { Social } \\
\text { inclusion }\end{array}$ \\
\hline $\begin{array}{l}24-30 \\
\text { April }\end{array}$ & $\begin{array}{l}\text { World Immunisation Week } \\
\text { Theme: 'Vaccines bring us closer'. More focussed on } \\
\text { routine vaccines than COVID-19. } \\
\text { https://www.who.int/news- } \\
\text { room/events/detail/2021/04/24/default-calendar/world- } \\
\text { immunization-week-2021 }\end{array}$ & $\begin{array}{l}\text { Governance } \\
\text { Social } \\
\text { inclusion }\end{array}$ \\
\hline $\begin{array}{l}\text { 14-20 } \\
\text { June }\end{array}$ & $\begin{array}{l}\text { Refugee Week } \\
\text { Theme: We cannot walk alone. } \\
\text { The crisis has highlighted how interconnected we are. } \\
\text { https://refugeeweek.org.uk/theme-of-refugee-week- } \\
\text { 2021-we-cannot-walk-alone/ }\end{array}$ & Humanitarian \\
\hline
\end{tabular}




\begin{tabular}{|l|l|l|}
\hline $\mathbf{9}$ August & $\begin{array}{l}\text { International Day of the World's } \\
\text { Indigenous Peoples } \\
\text { Theme: COVID-19 and indigenous peoples' resilience. } \\
\text { Looking at the capabilities indigenous people have } \\
\text { shown to adapt. } \\
\text { https://www.un.org/en/observances/indigenous-day }\end{array}$ & $\begin{array}{l}\text { Governance } \\
\text { Social } \\
\text { inclusion }\end{array}$ \\
\hline $\begin{array}{l}\mathbf{1 9} \\
\text { August }\end{array}$ & $\begin{array}{l}\text { World Humanitarian Day } \\
\text { injured in the course of their work. } \\
\text { https://www.un.org/en/observances/humanitarian-day }\end{array}$ & Humanitarian \\
\hline
\end{tabular}

\section{Anniversaries}

\begin{tabular}{|l|l|}
\hline Date & Timeline event \\
\hline $\begin{array}{l}\text { 31 December } \\
\mathbf{2 0 1 9}\end{array}$ & $\begin{array}{l}\text { A cluster of cases of pneumonia were reported in Wuhan China } \\
\text { which were eventually identified as a novel coronavirus. }\end{array}$ \\
\hline $\mathbf{1 3}$ January 2020 & First case identified outside of China, in Thailand. \\
\hline $\mathbf{1 1}$ March & WHO characterised COVID-19 as a pandemic. \\
\hline $\mathbf{4 8 - 1 9}$ May & $\begin{array}{l}\text { Over 1 million cases were confirmed worldwide. } \\
\text { virtually and adopted a landmark resolution to bring the world } \\
\text { together to fight the pandemic. }\end{array}$ \\
\hline $\mathbf{1 5}$ July & $\begin{array}{l}\text { The COVAX facility secured engagement from more than 150 } \\
\text { countries worldwide. }\end{array}$ \\
\hline $\mathbf{2 3}$ November & $\begin{array}{l}\text { AstraZeneca and Oxford University report their vaccine } \\
\text { candidate has at least 61\% efficacy, which found their }\end{array}$ \\
\hline
\end{tabular}




\begin{tabular}{|l|l|}
\hline & $\begin{array}{l}\text { formulations halted symptoms in up to 95\% of trial } \\
\text { participants. }\end{array}$ \\
\hline
\end{tabular}

\section{Suggested citation}

Bolton, L. (2021) Key Days and Events Relating to Covid-19, Covid Collective Helpdesk Report 4, Brighton: Institute of Development Studies, DOI: 10.19088/ CC.2021.004

\section{About this report}

This report is based on 3 days of desk-based research. The Covid Collective research helpdesk provides rapid syntheses of a selection of recent relevant literature and international expert thinking in response to specific questions relating to international development. For any enquiries, contact Covid Collective, Covidcollective@ids.ac.uk.

This evidence summary was funded by the UK Government's Foreign, Commonwealth and Development Office (FCDO) through the Covid Collective. It is licensed for non-commercial purposes only. Except

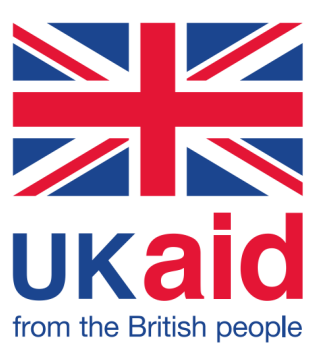
where otherwise stated, it is licensed for non-commercial purposes under the terms of the Open Government Licence v3.0. Covid Collective cannot be held responsible for errors, omissions or any consequences arising from the use of information contained. Any views and opinions expressed do not necessarily reflect those of FCDO, Covid Collective or any other contributing organisation.

(c) Crown copyright 2021. 